\title{
Measuring International Competitiveness in the Beef Sector
}

\author{
Dermot J. Hayes \\ John R. Green \\ Helen H. Jensen \\ Adrienne Erbach
}

Beef is a heterogenous commodity, which makes it difficult to compare beef prices on an international level. This article evaluates several methods of comparing beef prices for use in measuring both comparative advantage and the rate of protection. The most suitable method is one that compares the prices of wholesale cuts, adjusted for transportation costs.

The specific characteristics of meat greatly affect its price. Qualities such as the age and condition of the animal and the part of the animal from which a particular cut is taken greatly influence prices paid. These quality differences make international comparisons of meat products and prices more complex than those for standardized agricultural commodities, such as grains. And differences in the measurement of meat prices can lead to different conclusions on the degree of competitiveness within a country or competitive advantage among countries.

Some of the confusion over the appropriate measure of comparison arises

Journal Paper No. J-14130 of the lowa Agriculture and Home Economics Experiment Station, Ames, Iowa. Project No. 2835.

This material is based upon work supported by the Cooperative State Research Service, U.S. Department of Agriculture, under Agreement No. 89-38812-4480. Any opinions, findings, conclusions, or recommendations expressed in this article are those of the authors and do not necessarily reflect the view of the U.S. Department of Agriculture.

Funding for this research was also provided by the Iowa Beef Industry Council.

The authors are Assistant Professor, Research Assistant, and Associate Professor, respectively, Department of Economics, Iowa State University, and Research Assistant, University of Minnesota, St. Paul. 
because processing of most meats represents a relatively smaller share of the retail price than that for many other final products. Wheat becomes flour, for example, which in turn becomes bread. It would be unusual to use bread prices as the retail price of wheat, yet farm-gate, wholesale, and retail beef prices are commonly compared.

Several alternative methods exist for comparing beef prices across countries. These methods include average live-animal prices, standardized live-animal prices, average unit values for traded beef (i.e., exported), and retail and wholesale cut prices. The choice is further complicated by the need to adjust for the feed used, the meat's physical condition and temperature, and the presence or absence of contagiou's diseases in the country of origin. The best measure depends heavily on the purpose for which the comparison is made. Retail beef prices will be of interest to those considering consumer welfare, whereas farmgate prices will be of interest when producer welfare is the issue. Hahn et al. provide a good overview of the issues related to beef trade and multilateral trade reform. ${ }^{1}$

To date, it has been difficult to gather information on international meat prices; consequently, analysts have tended to use whatever measure was best supported by the available data. The measure most often used has been the average price received by producers (see, for example, General Agreement on Tariffs and Trade $^{2}$ ). As will be shown, this producer price measure has several significant disadvantages when the measure is to be used by those evaluating international meat products trade.

The purpose of this article is to compare each of several meat price measures, both in terms of the availability of data and implications of the measure itself for evaluating international meat products trade. The focus of this work is to arrive at the most suitable measure for determining a country's ability to compete in international markets. This measure is of interest because technological innovations in the meat transportation industry have led to increases in international meat sales and because the success of any multilateral liberalization of meat markets will depend on accurately measuring the degree to which current policies restrict trade. ${ }^{3}$ One very intuitive way of determining how much protection producers receive and thereby indirectly measuring the competitiveness of the industry is to measure the price wedge between world and domestic prices. This price wedge measure is very sensitive to the factors just discussed. Consequently, we devote most of our efforts to measures that can accurately be used to estimate this price wedge.

\section{MEASURING FARM-GATE BEEF PRICES}

Comparing steer and heifer prices received by producers across countries is difficult because producers customize their feeding and breeding practices to suit the demands of a particular marketplace. In the United States, for example, young animals are fed intensively on a corn-based diet and are slaughtered before their 18th month. In Australia and most of South America, animals are grass-fattened and are usually more than two years old when slaughtered. ${ }^{4}$ These different production practices result in different products.

One possible solution for minimizing the effects of these differences is to find beef products for which differences in production practices are less important. Meat from cows or mature bulls, for example, is usually used for manufacturing 
purposes and sold as ground or processed beef. American consumers do not differentiate between Australian grass-fed cow beef and US grass-fed (or grainfed) cow or bull beef. Thus, prices for these products are less likely to reflect underlying quality differences.

Table I shows contemporaneous cow prices for the principal market-oriented beef-producing countries of the world. The left-hand column presents the farmgate price of manufacturing beef in selected countries in US dollars $/ 100 \mathrm{~kg}$, and the right-hand column compares these prices to the US farm-gate price for 1986. The base year of 1986 was chosen because 1986 prices are most likely to be used in any current trade agreements and because these prices were readily available. As shown in Table I', South American producers seem to have a significant price advantage over all other producers; their nearest competitors are Australia and New Zealand. European beef prices are higher than those in the United States, whereas Japanese beef producers are highly protected.

One problem with this farm-gate measure is that it is useless for predicting trade patterns under liberalization because countries that are free of the virus causing foot-and-mouth disease cannot import from countries where the virus exists. Countries free of the virus include the United States, Canada, Australia, New Zealand, Japan, South Korea, the Scandinavian countries, the United Kingdom, and Ireland. These countries essentially form a closed trading bloc, excluding all but canned meat imports from the rest of the world. Of these countries, only Australia and New Zealand have a comparative advantage with the United States in farm-level cow production.

A second problem with using cow prices is that this measure tends to overprice US beef. Americans consume relatively more manufacturing beef than do con-

Table I. Comparison of Farm-Gate Prices for Cows for Selected Countries, 1986.

\begin{tabular}{lrr}
\hline Country & US $\$ / 100 \mathrm{~kg}$ & Ratio \\
\hline Argentina & 57.05 & 30.12 \\
Australia & 123.16 & 65.02 \\
Canada & 216.55 & 114.32 \\
Colombia & 93.42 & 49.32 \\
EC & 289.41 & 152.79 \\
Finland & 495.27 & 261.47 \\
Hungary & 99.71 & 52.64 \\
Japan & 923.74 & 487.67 \\
New Zealand & 79.22 & 41.82 \\
Norway & 453.33 & 239.33 \\
Sweden & 288.19 & 152.14 \\
Switzerland & 302.58 & 159.74 \\
Tunisia & 308.56 & 162.90 \\
United States & 189.42 & 100.00 \\
Uruguay & 88.11 & 46.52 \\
Yugoslavia & 186.17 & 98.28 \\
\hline
\end{tabular}

Source: Reference 2.

The US ratio equals 100.00 ; the ratios for the other countries are relative to that of the United States. 
sumers in the rest of the world, in large part because of the reliance on hamburger in US diets. Cow meat is used for hamburgers in the United States. This reliance tends to increase the price of cow meat in the United States relative to that of other types of beef.

A third problem with this approach is that prices reflect only the raw material price for meat exporters. Live animals are seldom sold to satisfy a demand for meat because the animals lose weight when transported and require expensive maintenance and specially constructed transportation mechanisms. In general, before meat is exported, animals must be transported to a slaughterhouse and processed into boxed or carcass beef. Then the meat must be shipped to its ultimate destination. There is every reason to believe that differences in the level of efficiency exist among the transportation and meat-processing industries in countries free of the foot-and-mouth disease virus.

These three problems limit the appropriateness of using cow prices as a general measure of competition in international markets.

\section{MEASURING UNIT IMPORT/EXPORT RATIOS}

For many agricultural commodities such as wheat or sugar, the average import price is commonly used to represent the traded price of a particular commodity. These averages are often quoted as freight and shipping (FAS) prices and are used extensively by economists.

Table II presents the unit import and unit export ratios of the principal countries free of the foot-and-mouth disease virus. These price ratios are expressed in proportion to those for the United States. The United Kingdom is representative of the European countries free of the foot-and-mouth disease virus. Here, the reliance of US beef importers on manufacturing beef is clear; US unit import values are lower than those for any other country. Conversely, the unit import value for Japan is very high. These unit import ratios simply reflect the prices received by the exporter and the shipper and do not reflect the quota rents in Japan. Some Japanese importers are licensed to import a certain quantity of beef

Table II. Comparison of Unit Import and Unit Export Values for Beef for Principal Countries Free of the Foot-and-Mouth Disease Virus, 1986.

\begin{tabular}{lrc}
\hline Country & Export Ratio $^{a}$ & Import Ratio $^{b}$ \\
\hline Australia & 106.59 & 152.43 \\
Canada & 95.54 & 157.71 \\
Japan & $1,241.57$ & 170.60 \\
New Zealand & 165.47 & 119.31 \\
United Kingdom & 142.77 & 120.95 \\
United States & 100.00 & 100.00 \\
\hline
\end{tabular}

Source: Reference 2.

aThe export ratio is calculated as the country's FOB export unit price relative to the US FOB export unit price.

bThe import ratio is calculated as the country's CIF import unit price relative to the US CIF import unit price. 
for which the specifications are determined by the importer. To maximize their quota rents, importers tend to import only the more expensive middle cuts (i.e., steaks and fillets).

The heterogeneity of beef makes this unit import/export measure useless. When Japan lifts its beef quota in April 1991, the relative price of imported boxed carcasses will fall and importing full sets or entire boxed carcasses will become more economical, which will result in a reduction in Japan's unit import value and in the unit export values of the suppliers. In particular, Japan has not limited the quantity of imported diaphragm beef. This beef is inexpensive relative to middle cuts and tends to reduce the US and Australian unit export values and Japan's unit import value, thereby partly offsetting the bias toward middle cuts discussed earlier. Any shift in Japanese preference between US and Australian diaphragm beef would change the unit export values of these countries but would in no way reflect any change in competitiveness between the United States and Australia.

\section{MEASURING WHOLESALE PRICE CUTS BY COMPARING WHOLESALE BOXED.BEEF PRICES}

Much of the world's beef is traded as primal or subprimal cuts, packaged in boxes that may contain several identical cuts or several cuts from the same carcass. It is not uncommon for a country or region to simultaneously import certain cuts and to export others. The increased reliance on individual meat cuts rather than on entire carcasses enables meat traders to satisfy local market conditions by purchasing only cuts that are in demand.

Because trade occurs between wholesale markets in different countries and because much of this trade is in boxed beef, wholesale prices of beef cuts are an obvious choice for comparison of protection levels and comparative advantage. Price comparisons based on wholesale cuts reflect some of the heterogeneity of beef products and are based on the product actually traded. The obvious disadvantage of this approach is the comparability of the data. Each country has different cutting practices, and even where cutting practices are similar, different terms are used to describe the same cuts.

This wholesale-cuts price comparison is most useful for measuring the protection level afforded to different beef industries. Consider the following simplified example. Consumers in country A prefer the cheaper forequarter beef cuts; consumers in country B are similar in every respect except that they prefer hindquarter cuts. Suppose that each country imposes a prohibitive tariff. This tariff may well be invisible when average prices or live-animal prices are used. However, if tariffs were measured based on the traded cuts, large protection levels could be measured. With the removal of these tariffs, beef forequarters would move from country $A$ to country $B$ and hindquarters would move in the opposite direction, yet average beef prices would be similar in both countries. The government in either country could construct a situation in which average tariff levels were lower than the true measure. For example, country A could impose a high tariff on beef forequarters and a low tariff on hindquarters and argue that the average tariff was low.

The example just described is extreme, but it portrays some real issues in international meat trade. For example, the United States simultaneously imports 
large quantities of low-quality beef and exports beef offal and high-quality beef cuts. Also, US demand for different beef cuts is seasonal; cheaper cuts are in high demand in the spring, and more expensive cuts are demanded during the summer months.

\section{CHOICE OF CUTS FOR INTERNATIONAL COMPARISON}

To make comparison of wholesale cuts, specific cuts for comparison from each country must be selected. Several considerations are important in making the choice. Comparing cuts among countries will be most straightforward for cuts consisting of an individual muscle separated at the bone. Other factors important in determining appropriate cuts for comparison are market popularity, the percentage of the primal that the subprimal cut represents, and some representation of the whole carcass. These criteria were used to identify a set of specific cuts for comparison as shown in Table III.

Figure 1 shows the different names and locations of selected cuts in each of the countries free of the foot-and-mouth disease virus. In the beef forequarter, subprimals of the chuck and brisket were chosen. The beef chuck/shoulder clod consists of three muscles removed at the seams. This cut is found in the cutting guides of Australia, New Zealand, the United Kingdom, and Japan. Also, the beef chuck/chuck tender is used because it includes only the supraspinatus muscle and is easy to identify in other markets.

The brisket also consists of a single, long muscle. This factor is important because, although the brisket is a popular cut internationally, it is usually cut into two parts that are not the same in every market. Because the muscle is relatively lean, a weight measure would allow accurate price comparisons. Therefore, even where the brisket is halved, the cutting method would not hinder comparison.

Table III. Subprimal Beef Cuts that Can Be Used in International Comparisons.

\begin{tabular}{|c|c|c|c|c|}
\hline $\begin{array}{l}\text { United } \\
\text { States }\end{array}$ & $\begin{array}{l}\text { United } \\
\text { Kingdom }\end{array}$ & Australia & Japan & Canada \\
\hline $\begin{array}{c}\text { Square Cut } \\
\text { Chuck }\end{array}$ & Chuck & Chuck & $\begin{array}{c}\text { Square Cut } \\
\text { Chuck }\end{array}$ & Chuck \\
\hline Brisket & Brisket & Brisket & Brisket & Brisket \\
\hline Top Sirloin & Rump & Rump & Sirloin & Sirloin \\
\hline $\begin{array}{c}\text { Ribeye Roll } \\
\text { (Lip On) }\end{array}$ & Cube Roll & Rib Roast & $\begin{array}{c}\text { Ribeye Roll } \\
\text { (Lip On) }\end{array}$ & Rib \\
\hline Striploin & Striploin & Sirloin Roast & Striploin & Short Loin \\
\hline Tenderloin & Fillet & Fillet & Tenderloin & Fillet \\
\hline $\begin{array}{c}\text { Top Inside } \\
\text { Round }\end{array}$ & Inside Round & Top Side & Top Round & $\begin{array}{c}\text { Top Inside } \\
\text { Round }\end{array}$ \\
\hline
\end{tabular}

Sources:United States information, Reference 5.

United Kingdom information, Reference 6.

Australia information, Reference 7.

Japan-US definition cuts commonly traded in Japanese wholesale markets.

Canada information, Reference 8. 

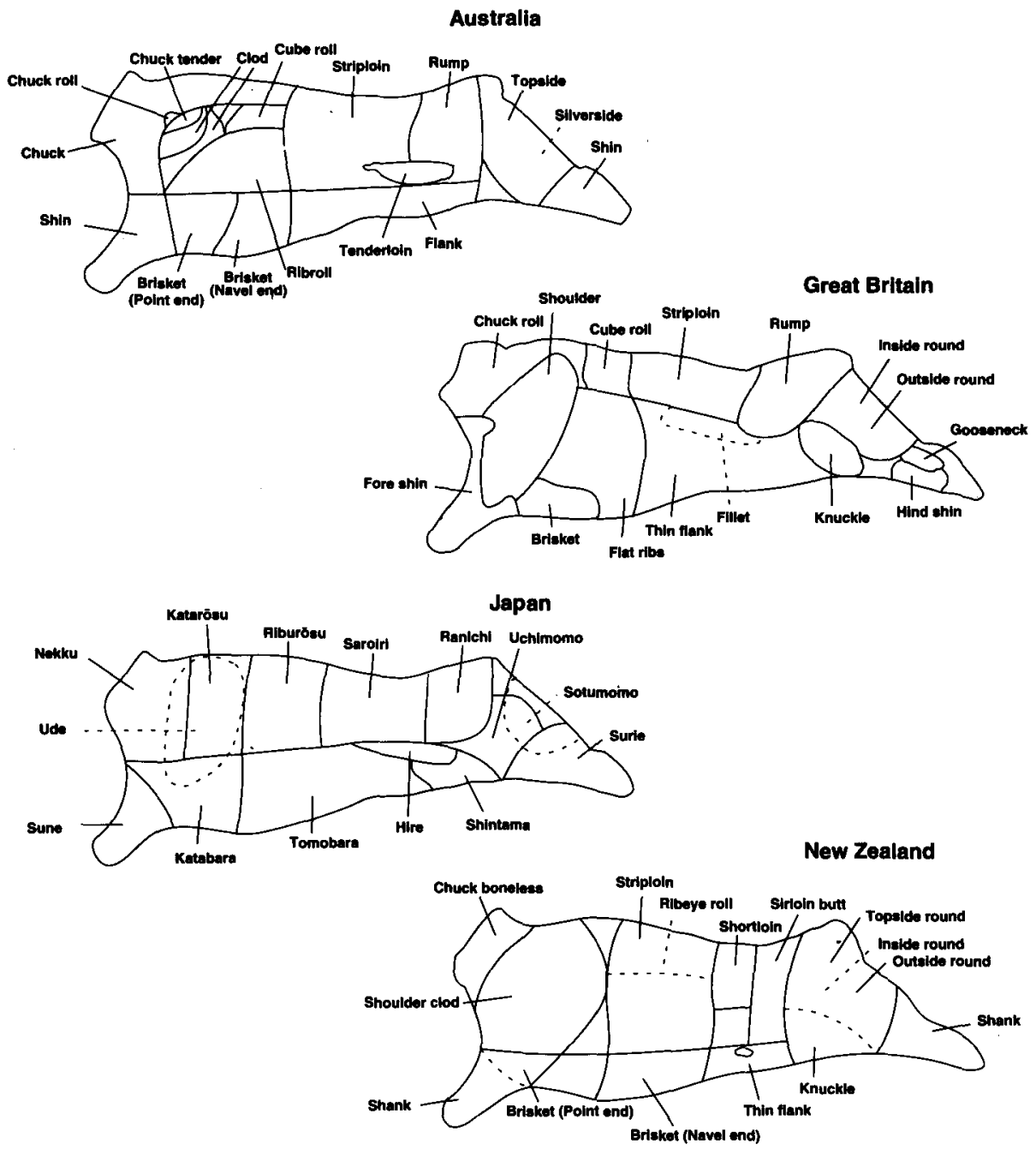

United States and Canada

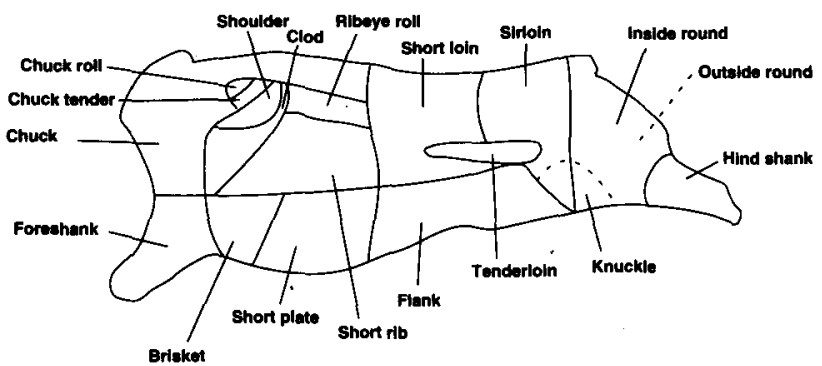

Figure 1. Names and Locations of Selected Cuts in Countries Free of Foot-andMouth Disease. 
Ribs were not included in the comparison. Although ribs are frequently traded and are popular in some countries, difficulties exist in comparing rib cuts because of the many variations in the way the rib is broken down into subprimal cuts. The muscle sizes vary greatly between the chuck and the loin ends. Also, the amount of bone removed would be difficult to determine.

Some representative hindquarter cuts include those from the top inside round, flank, and tenderloin. From the round area, the top inside round, trimmed (or untrimmed), was chosen. The top inside round is traded internationally and represents a large percentage of the round. The tenderloin is an acceptable cut because it is an internationally traded cut and consists of a single muscle. The flank could also be used, even though it is not popular in the marketplace. This cut has little fat and bone and is similar in most countries, so a good price comparison would be possible. The knuckle might also be chosen to represent the poorer quality cuts from the round area.

Table IV compares the price of the selected cuts in April 1987 and January 1989. (This information was not available for all the countries before April 1987.) The most surprising aspect of these numbers is the relative cost of beef cuts in the United States and Australia. As shown, Australia's comparative advantage in farm-gate cow prices is greatly reduced when wholesale-cut prices are used, particularly for the 1989 numbers. Also, note the competitiveness of UK beef producers for certain cuts. Both the Australian and UK prices are for grass-fed beef, whereas the US, Japanese, and Canadian prices are for corn-fed beef.

The prices in Table IV come close to satisfying the requirements for measuring international competitiveness. However, adjustments for relevant transportation

Table IV. Wholesale Chilled Beef Prices by Cut (US Dollars/Pound).

\begin{tabular}{lrrrrr}
\hline & Australia & Canada & $\begin{array}{c}\text { Japan } \\
\text { (Imported) }\end{array}$ & $\begin{array}{c}\text { United } \\
\text { Kingdom }\end{array}$ & $\begin{array}{r}\text { United } \\
\text { States }\end{array}$ \\
\hline April 1987 & & & & & \\
$\quad$ Top Sirloin & $\$ 1.38$ & $\$ 1.70$ & $\$ 4.23$ & $\$ 1.88$ & $\$ 1.50$ \\
Top Round & 1.14 & 1.43 & 3.67 & 1.20 & 1.87 \\
Square-Cut Chuck & 0.81 & 0.98 & 2.86 & 0.82 & 1.26 \\
Brisket & 0.80 & 0.70 & 2.37 & 0.86 & 0.94 \\
Ribeye & 1.55 & 2.89 & 7.86 & 2.47 & 3.08 \\
January 1989 & & & & & \\
Top Sirloin & 2.19 & 1.80 & 4.12 & 2.02 & 1.80 \\
Top Round & 1.58 & 1.64 & 4.17 & 1.30 & 1.58 \\
Square-Cut Chuck & 1.17 & 1.13 & 3.64 & 0.91 & 1.45 \\
Brisket & 1.04 & 0.67 & 2.93 & 0.93 & 1.08 \\
Ribeye & 2.94 & 3.53 & 8.19 & 2.83 & 3.76 \\
\hline
\end{tabular}

Sources: Australia information, Reference 9.

Canada information, Reference 8.

Japan information, Reference 10.

United Kingdom information, Reference 11.

United States information, Reference 12.

Exchange rates are based on information from International Financial Statistics. ${ }^{13}$ 
costs must be made before these prices can be used. To include this adjustment, we have calculated the bilateral tariff equivalents for all the cuts and time periods by combining the price in country $A$ with the transportation costs from country $A$ to country $B$ and comparing these costs with the wholesale prices in country B. The difference between the price of meat cuts in country $B$ and the price of comparable meat cuts from country A being sold in country B (adjusted for transportation costs) is expressed as a percentage of the delivered price. This tariff equivalent is therefore the ad valorem rate that would maintain current trade flows. If this number is negative, country A would need a subsidy to maintain current trading levels. The numbers are presented in Tables $\mathrm{V}$ through IX. Table $\mathrm{V}$ shows that Australia would need to subsidize beef imports to attract meat from abroad that is free of the foot-and-mouth disease virus.

The implication of Tables V through IX is that Australia is not going to become a major export market in the near future because almost all of the tariff equivalents are negative. However, Japan is currently a profitable export market for all cuts and countries represented. The numbers for the United Kingdom, Canada, and the United States demonstrate one of the principal strengths of this measure; namely, that certain cuts could successfully be interchanged between countries. For example, the United Kingdom could export ribeye to Canada (Table VI) and profitably import brisket (Table VIII). The magnitude of the numbers between the United States and Canada are of interest, given that beef products move relatively freely between the two countries and at relatively low cost. There does not seem to be a lot of export potential for US boxed beef in Canada (Table VI), and only brisket and square-cut chuck would provide a reasonable rate of return in the opposite direction (in 1989) (Table IX).

The numbers presented here demonstrate apparent seasonality. Figures 2 through 10 show some selected comparisons between prices of two countries throughout the year. Figures 2 through 5 show how the United States and Australia compare. Although obvious in hindsight, it is surprising to note how the seasonality in Australia is so different from that in the United States. The obvious reason is that the seasons are reversed in the Southern Hemisphere.

Table V. Australian Tariff Equivalents.

\begin{tabular}{|c|c|c|c|c|c|}
\hline & Australia & Canada & Japan & $\begin{array}{c}\text { United } \\
\text { Kingdom }\end{array}$ & $\begin{array}{l}\text { United } \\
\text { States }\end{array}$ \\
\hline \multicolumn{6}{|l|}{ April 1987} \\
\hline Top Sirloin & - & -32.02 & -68.85 & -36.70 & -24.59 \\
\hline Top Round & - & -35.23 & -70.54 & -24.00 & -48.18 \\
\hline Square-Cut Chuck & - & -38.17 & -73.53 & -27.68 & -49.06 \\
\hline Brisket & - & -22.33 & -68.87 & -31.03 & -37.01 \\
\hline Ribeye & - & -51.86 & -80.77 & -44.04 & -54.55 \\
\hline \multicolumn{6}{|l|}{ January 1989} \\
\hline Top Sirloin & - & 2.82 & -49.31 & -5.60 & 2.82 \\
\hline Top Round & - & -19.80 & -63.84 & -1.25 & -17.28 \\
\hline Square-Cut Chuck & - & -19.86 & -69.53 & -3.31 & -34.27 \\
\hline Brisket & - & 4.00 & -66.77 & -15.45 & -26.24 \\
\hline Ribeye & - & -23.83 & -64.96 & -6.07 & -28.12 \\
\hline
\end{tabular}


Table VI. Canadian Tariff Equivalents.

\begin{tabular}{lrrrrr}
\hline & & & & $\begin{array}{c}\text { United } \\
\text { Kingdom }\end{array}$ & $\begin{array}{r}\text { United } \\
\text { States }\end{array}$ \\
\hline April 1987 & Australia & Canada & Japan & Kito \\
$\quad$ Top Sirloin & 7.59 & - & -62.05 & -16.26 & 6.25 \\
Top Round & 6.72 & - & -63.52 & 5.93 & -27.41 \\
Square-Cut Chuck & -2.97 & - & -68.49 & 1.03 & -27.94 \\
Brisket & -30.00 & - & -73.28 & -30.69 & -32.69 \\
Ribeye & 65.14 & - & -64.36 & 10.31 & -9.12 \\
January 1989 & & & & & \\
Top Sirloin & -24.69 & - & -58.81 & -17.05 & -5.26 \\
Top Round & -7.87 & - & -62.90 & 13.10 & -2.38 \\
Square-Cut Chuck & -17.52 & - & -70.95 & 6.60 & -27.10 \\
Brisket & -45.97 & - & -78.93 & -37.96 & -43.22 \\
Ribeye & 12.42 & - & -58.18 & 18.46 & -8.55 \\
\hline
\end{tabular}

Figure 6 compares the prices of top sirloin in the United Kingdom and the United States. Again, the seasonal variations are of greatest interest. Even though in the same hemisphere, consumer preferences and, perhaps, differences in production methods seem to dictate the differences, giving the United States export opportunities in winter and the United Kingdom export opportunities (in the United States) in summer.

Other factors, of course, also affect relative price movements. For example, Australian prices have risen at a faster rate than have US prices. One explanation for this trend might be the enormous increase in Australian beef exports to Japan

Table VII. Japanese Tariff Equivalents.

\begin{tabular}{|c|c|c|c|c|c|}
\hline & Australia & Canada & Japan & $\begin{array}{c}\text { United } \\
\text { Kingdom }\end{array}$ & $\begin{array}{l}\text { United } \\
\text { States }\end{array}$ \\
\hline \multicolumn{6}{|l|}{ April 1987} \\
\hline Top Sirloin & 167.72 & 116.92 & - & 81.55 & 141.71 \\
\hline Top Round & 173.88 & 118.45 & - & 122.42 & 73.11 \\
\hline Square-Cut Chuck & 183.17 & 132.52 & - & 125.20 & 89.40 \\
\hline Brisket & 137.00 & 149.47 & - & 80.92 & 99.16 \\
\hline Ribeye & 349.14 & 150.32 & - & 169.18 & 136.04 \\
\hline \multicolumn{6}{|l|}{ January 1989} \\
\hline Top Sirloin & 72.38 & 100.98 & - & 66.80 & 100.98 \\
\hline Top Round & 134.27 & 120.63 & - & 138.29 & 127.87 \\
\hline Square-Cut Chuck & 165.69 & 163.77 & - & 167.65 & 114.12 \\
\hline Brisket & 136.29 & 218.48 & - & 112.32 & 120.30 \\
\hline Ribeye & 160.83 & 116.67 & 一 & 149.70 & 104.24 \\
\hline
\end{tabular}


Table VIII. UK Tariff Equivalents.

\begin{tabular}{|c|c|c|c|c|c|}
\hline & Australia & Canada & Japan & $\begin{array}{c}\text { United } \\
\text { Kingdom }\end{array}$ & $\begin{array}{l}\text { United } \\
\text { States }\end{array}$ \\
\hline \multicolumn{6}{|l|}{ April 1987} \\
\hline Top Sirloin & 11.90 & 1.62 & -59.83 & - & 13.94 \\
\hline Top Round & -16.67 & -24.05 & -70.87 & - & -40.59 \\
\hline Square-Cut Chuck & -26.13 & -27.43 & -75.23 & - & -41.84 \\
\hline Brisket & -21.82 & 1.18 & -69.50 & - & -21.10 \\
\hline Ribeye & 33.51 & -18.75 & -70.28 & - & -23.53 \\
\hline \multicolumn{6}{|l|}{ January 1989} \\
\hline Top Sirloin & -18.88 & 3.59 & -55.80 & - & 3.59 \\
\hline Top Round & -30.85 & -27.37 & -71.86 & - & -24.86 \\
\hline Square-Cut Chuck & -38.10 & -28.91 & -77.75 & - & -43.12 \\
\hline Brisket & -30.60 & 13.41 & -72.49 & - & -24.39 \\
\hline Ribeye & -12.65 & -23.10 & -67.25 & - & -27.62 \\
\hline
\end{tabular}

and South Korea, which have been far greater as a proportion of domestic production than have US exports to Japan. Also, the large run-up in UK prices that began in January 1989 may be attributable in part to the implementation of the EC hormone ban, which became effective on that date.

Figures 7 through 10 compare US and Canadian prices. In these figures, the seasonal patterns are similar. Chuck roll prices in the United States are lower than those in Canada, whereas the prices of ribeyes and briskets are lower in Canada. The reason for the Canadian competitive position in ribeyes may be attributable to the Canadian preference for leaner (and therefore cheaper) steaks.

Table IX. US Tariff Equivalents.

\begin{tabular}{|c|c|c|c|c|c|}
\hline & Australia & Canada & Japan & $\begin{array}{c}\text { United } \\
\text { Kingdom }\end{array}$ & $\begin{array}{l}\text { United } \\
\text { States }\end{array}$ \\
\hline \multicolumn{6}{|l|}{ April 1987} \\
\hline Top Sirloin & -12.28 & -16.67 & -66.52 & -26.11 & - \\
\hline Top Round & 27.21 & 22.22 & -52.30 & 38.52 & - \\
\hline Square-Cut Chuck & 10.53 & 16.67 & -59.49 & 29.90 & - \\
\hline Brisket & -16.81 & 17.50 & -64.12 & -6.93 & - \\
\hline Ribeye & 63,83 & 3.01 & -62.02 & 17.56 & - \\
\hline \multicolumn{6}{|l|}{ January 1989} \\
\hline Top Sirloin & -28.57 & -5.26 & -58.81 & -17.05 & - \\
\hline Top Round & -17.28 & -9.20 & -64.25 & 8.97 & - \\
\hline Square-Cut Chuck & -3.33 & 17.89 & -62.72 & 36.79 & 一 \\
\hline Brisket & -21.17 & 40.26 & -66.04 & 0.00 & - \\
\hline Ribeye & 14.98 & 3.58 & -55.45 & 26.17 & - \\
\hline
\end{tabular}




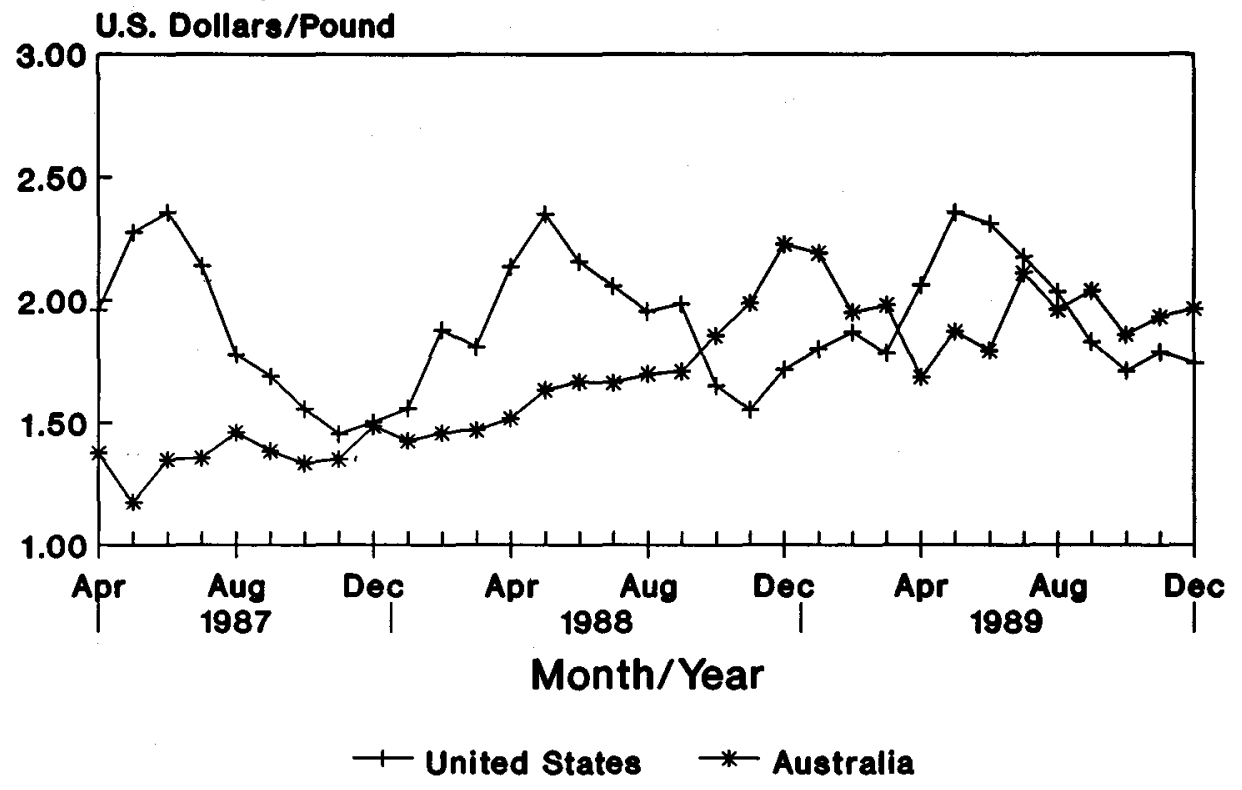

Figure 2. Wholesale Prices of US and Australian Top Sirloin.

Sources: References 9 and 12.
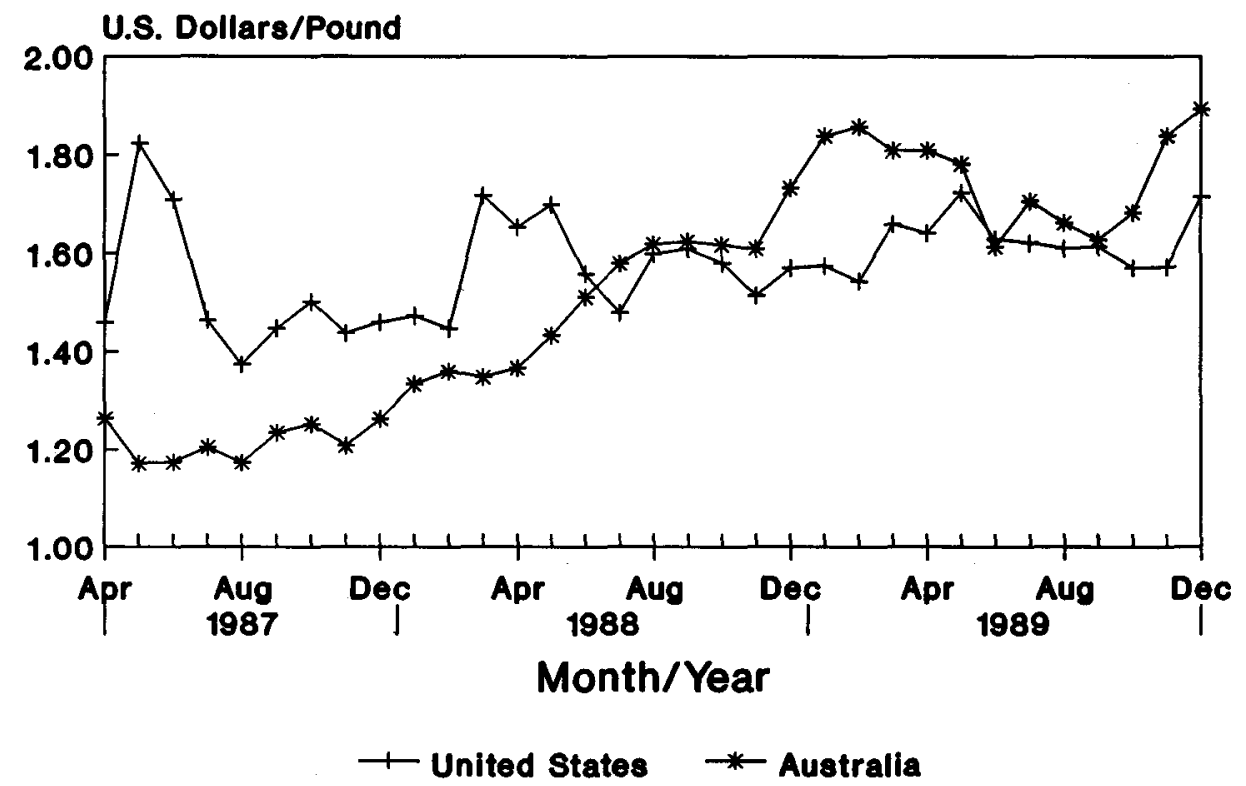

Figure 3. Wholesale Prices of US and Australian Top Round.

Sources: References 9 and 12. 


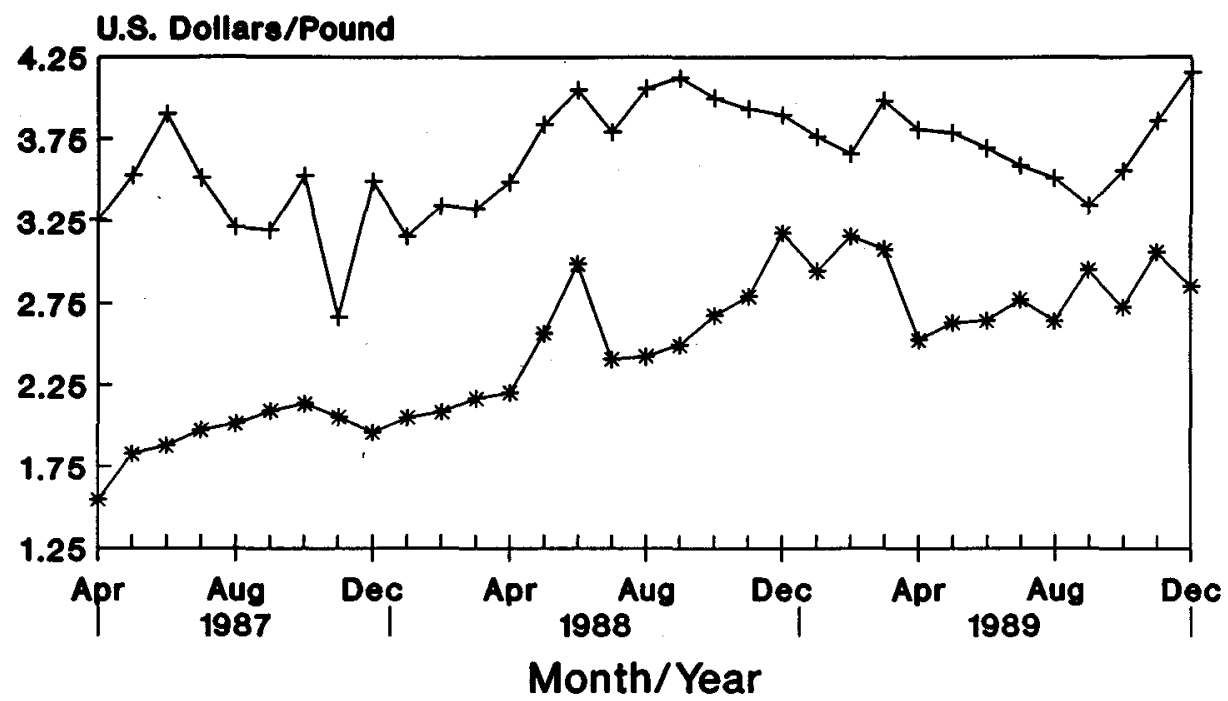

十 United States * Australia

Figure 4. Wholesale Prices of US and Australian Ribeye Roll.

Sources: References 9 and 12.

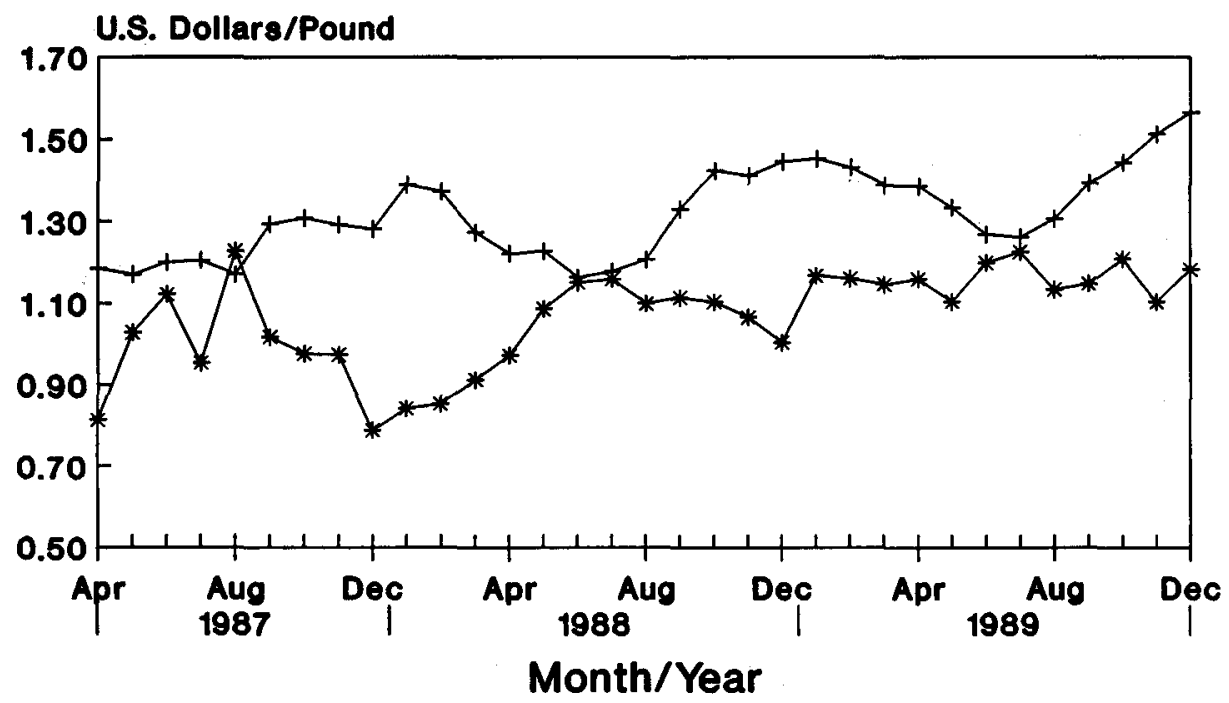

\section{T United States * Australia}

Figure 5. Wholesale Prices of US and Australian Chuck Roll.

Sources: References 9 and 12. 


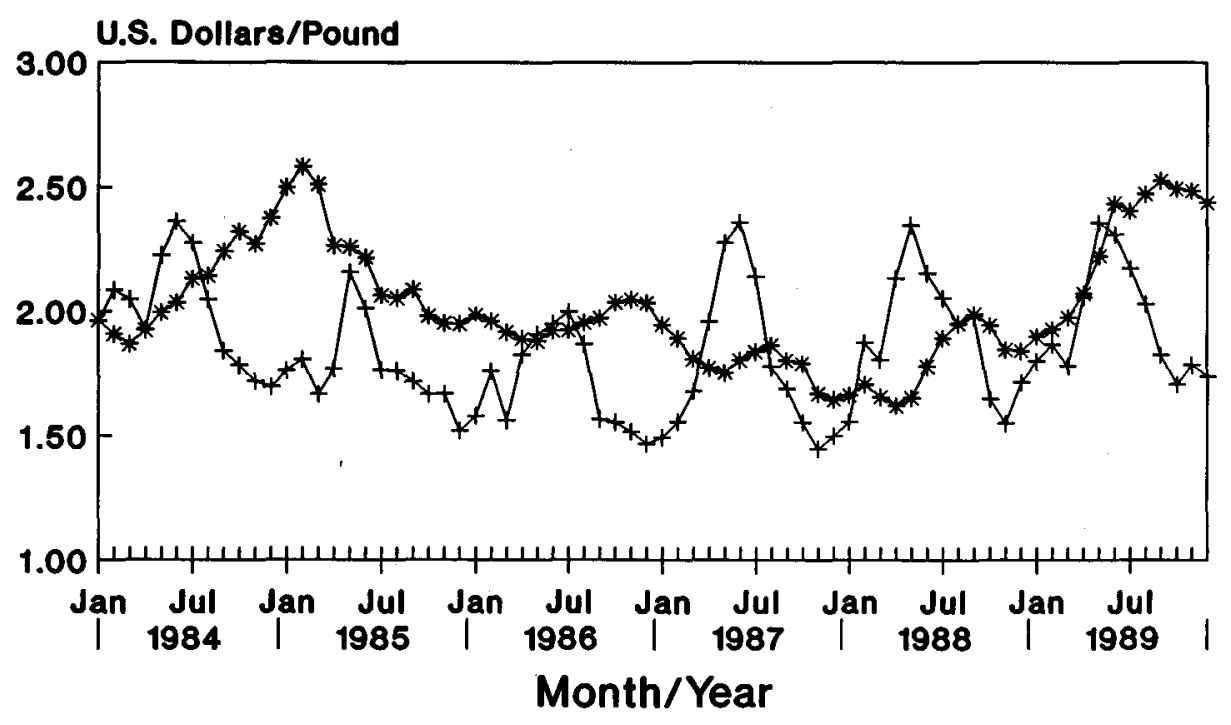

\section{T United States $\quad *$ United Kingdom}

Figure 6. Wholesale Prices of US and UK Top Sirloin.

Sources: References 12 and 14.

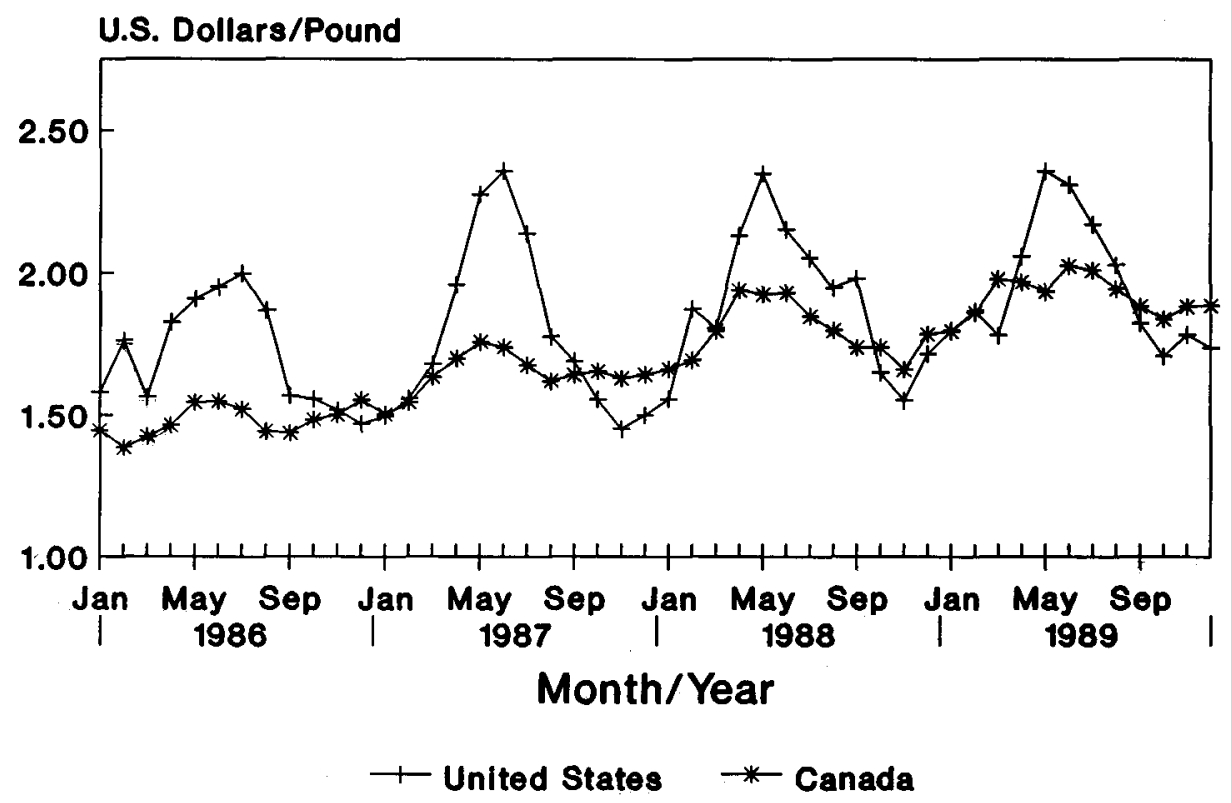

Figure 7. Wholesale Prices of US and Canadian Top Sirloin.

Sources: References 8 and 12. 
U.S. Dollars/Pound

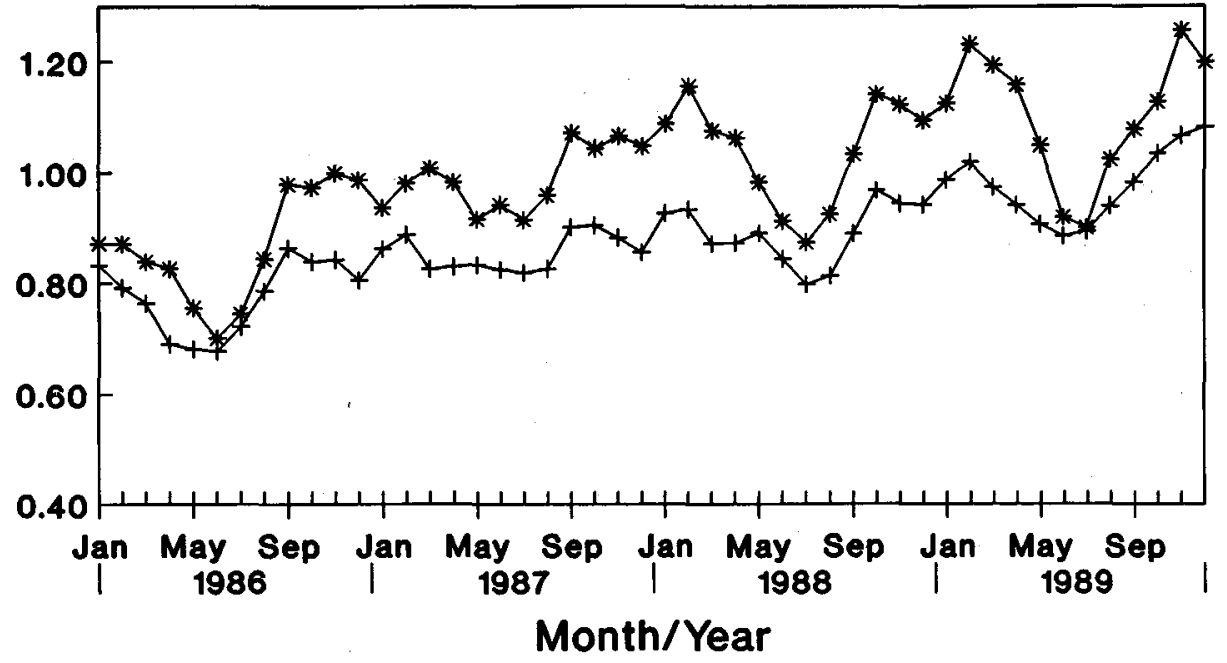

+ United States $\rightarrow$ - Canada

Figure 8. Wholesale Prices of US and Canadian Chuck Roll.

Sources: References 8 and 12.

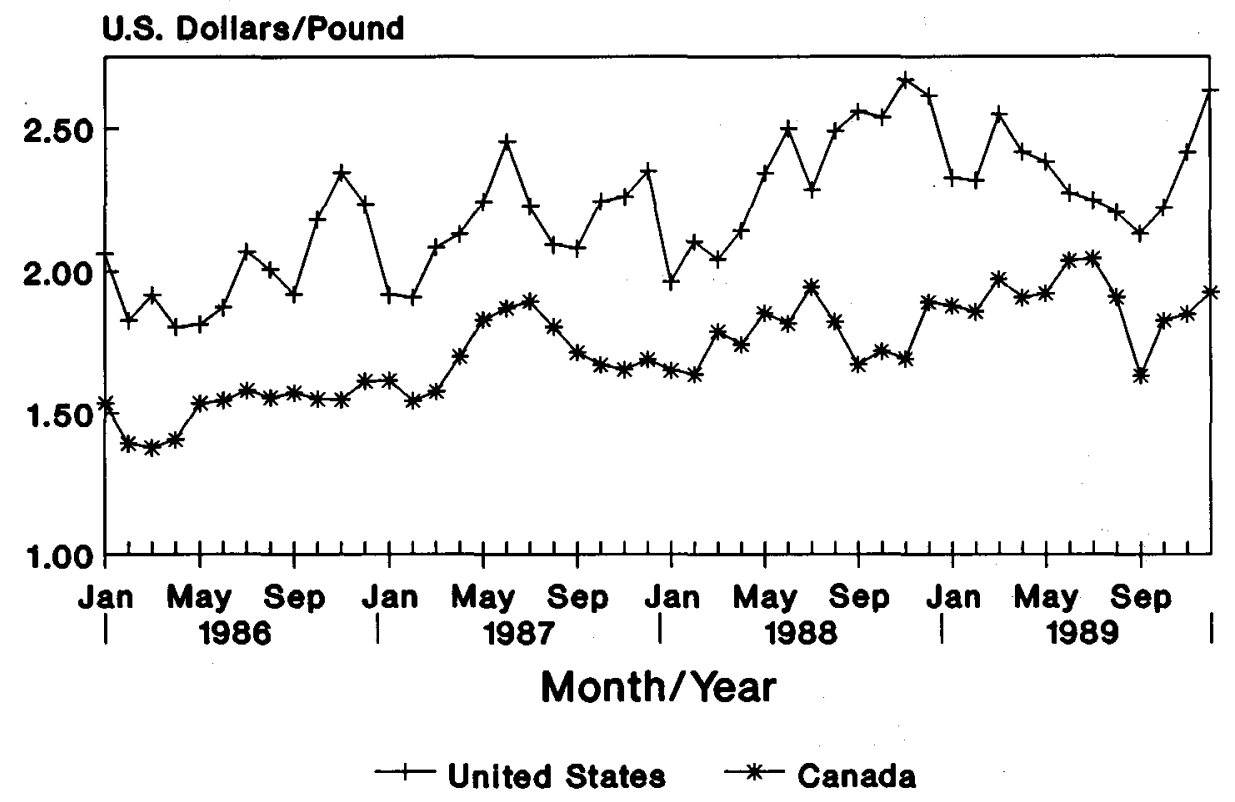

Figure 9. Wholesale Prices of US and Canadian Ribeye Roll.

Sources: References 8 and 12. 


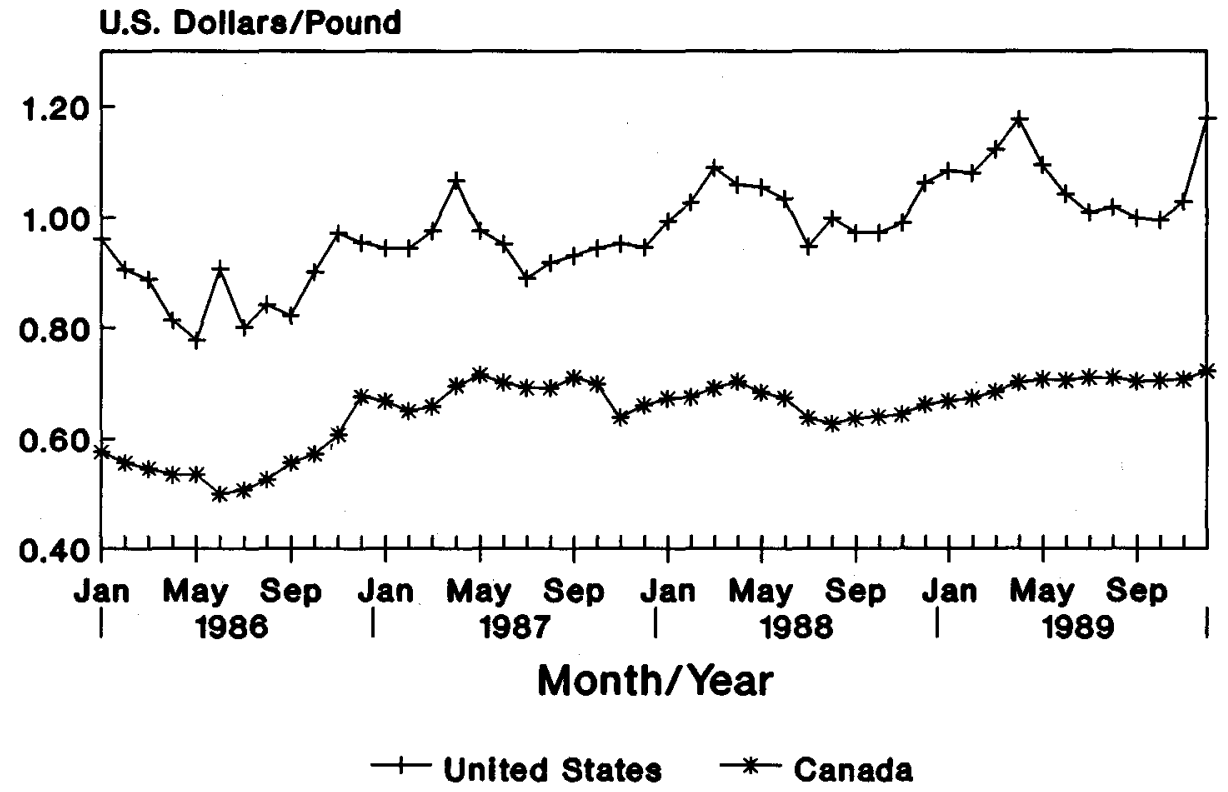

Figure 10. Wholesale Prices of US and Canadian Brisket. Sources: References 8 and 12.

\section{MEASURES USING RETAIL CUT PRICES}

Comparable retail beef price measures for meat products are difficult to find. For example, the United States calculates a weighted average price for beef, whereas Australia quotes a representative cut (sirloin). Table X shows how retail prices compare across countries. Again, the surprising feature is the high cost of the

Table X. Retail Sirloin Prices, 1987.

\begin{tabular}{lcc}
\hline Country & Cut & $\begin{array}{c}\text { Price } \\
\text { (US } \$ / \text { lb) }\end{array}$ \\
\hline Australia & Sirloin/Rump & 2.78 \\
Canada & Sirloin & 3.79 \\
Japan & Sirloin & 12.55 \\
New Zealand & Sirloin & 1.56 \\
United Kingdom & Sirloin & 6.47 \\
United States & Sirloin & 2.98 \\
\hline
\end{tabular}

Sources: Australia, Canada, Japan, and New Zealand information, Reference 2.

United Kingdom information, Reference 14.

US information: Data collected from grocery store.

Exchange rates = Australian $\$ 1.4067 /$ US $\$ 1$.

British $£$ 0.547/US $\$ 1$.

Canadian $\$ 1.3074 /$ US $\$ 1$.

Japanese $¥ 128.59 /$ US $\$ 1$.

New Zealand \$1.6886/US \$1. 
Australian product. Although not shown here, Australian consumers pay more for grass-fed rump steak than US consumers pay for corn-fed rump steak.

It is interesting to speculate why Australia loses its competitive advantage when price comparisons are made further up the processing chain. One possibility is that beef costs significantly more to transport, slaughter, and process in Australia than it does in the United States. This factor may be attributable to longer haulage distances, smaller packing plants, and a more highly unionized work force in Australia. If this is so, then for purposes of international comparison, Australia's advantage in live-animal production and its disadvantage in all other aspects of the process should be considered together in comparing each country's ability to produce the product that is actually traded on world markets.

\section{CONCLUSIONS}

Beef is a heterogeneous commodity, and much useful information is lost if we use beef prices in international comparisons rather than the prices of the goods actually traded (i.e., boxed beef cuts). In this article, we have examined several methods for comparing prices. These methods produced surprisingly different results. By using farm-gate prices, South American, Australian, and New Zealand producers seem to have a significant price advantage over European, US, and Japanese beef producers. For comparisons at the wholesale-cuts level for foot-and-mouth disease-free countries, however, Australia's competitive advantage is greatly reduced. At this level, European (UK) and US industries are competitive in the world market for certain cuts at certain times. These results indicate that the US comparative advantage among countries free of foot-andmouth disease is much better than one would believe by comparing manufacturing beef prices.

The feasibility of evaluating competitiveness by using these alternative measures, of course, is dependent on the availability of data. We have shown that, by following consistent criteria for selecting cuts, it is possible to identify comparable cuts and find prices for comparison. With an increasing share of international beef trade being conducted as boxed beef, measures of competitiveness that reflect the true nature of the traded product are superior.

\section{REFERENCES}

1. W.F. Hahn, T.L. Crawford, L. Bailey, and S. Shagam, The World Beef Market-Government Intervention and Multilateral Policy Reform, US Department of Agriculture, Washington, DC, 1990.

2. General Agreement on Tariffs and Trade, The International Market for Meat, 1988/89, Arrangement Regarding Bovine Meat, Ninth Annual Report, General Agreement on Tariffs and Trade, Geneva, 1989.

3. D.K. Elton, W.A. Kerr, K.K. Klein, and E.T. Penner, Eds., Selling Beef to Japan . . A Resource Guide for Exporters, Canada West Foundation, Calgary, 1990.

4. James R. Simpson, and Donald E. Farris, The World's Beef Business, Iowa State University Press, Ames, IA, 1982.

5. American Meat Institute, Meat Facts. Washington, DC, American Meat Institute, 1988.

6. Irish Fresh Meat Exporters Society, Ltd. and An Foras Taluntais, BBC Beef Cuts Code, 2nd ed., An Foras Taluntais, Dublin, 1980.

7. Australian Meat and Livestock Corporation, Nutrition and Education Section, A Vital Industry: Meat and Livestock in Australia, Australian Meat and Livestock Corporation, Sydney, 1988. 
8. Agriculture Canada, Canada Livestock and Meat Trade Report, Market Information Service, Agriculture Development Branch, January 1986-December 1989.

9. Australian Meat and Livestock Corporation, Communication received by the Meat Export Research Center, Iowa State University, Ames, February 1990.

10. Shokuniku Kai, Special Edition, Shokuniku Tsushin-Sah, Osaka, Japan, 25 13(November 1988) and 27 2(February 1990).

11. Australian Meat and Livestock Corporation, The Meat Producer and Exporter, 43 1(January 1989).

12. US Department of Agriculture, Agricultural Marketing Service, "Fabricated Boxed Beef Cuts," in Market News: Weekly Summary and Statistics, US Department of Agriculture, Washington, DC, various issues, 1987-1989.

13. International Financial Statistics, International Monetary Fund, Washington, DC, various issues.

14. Meat and Livestock Commission, United Kingdom, Communication received by the Meat Export Research Center, Iowa State University, Ames, February 7, 1990. 
Iowa State University does not discriminate on the basis of race, color, age, religion, national origin, sexual orientation, gender identity, sex, marital status, disability, or status as a U.S. veteran. Inquiries can be directed to the Director of Equal Opportunity and Diversity, 3680 Beardshear Hall, (515) 294-7612. 